\title{
Evaluation of Carbonylated Proteins in Hepatitis C Virus Patients
}

\author{
Mahmoud Mohamed Alou-El-Makarem ${ }^{1 *}$, Moussa Madany Moustafa', Mohamed Abdel-Aziz Fahmy ${ }^{1}$, Aamer Mohamed Abdel-Hamed ${ }^{1}$, \\ Khaled Nagy El-fayomy ${ }^{3}$ and Medhat Mohamed Abdel-Salam Darwish ${ }^{2}$ \\ ${ }^{1}$ Department of Medical Biochemistry, Al Azhar University, Cairo, Egypt \\ ${ }^{2}$ Faculty of Medicine, Al Azhar University, Damietta, Cairo, Egypt \\ ${ }^{3}$ Department of Internal Medicine, Al Azhar University, Damietta, Cairo, Egypt
}

\begin{abstract}
Carbonylated proteins are irreversible posttranslational oxidative modifications, which may interfere with the normal homeostasis of cell growth inducing liver cirrhosis and risk of malignancy.

Objective: To determine plasma levels of carbonylated proteins and total antioxidant capacity and evaluate their role in HCV hepatitis patients and HCV induced liver cirrhosis before and after antiviral therapy; interferon and ribavirin.

Methods: This study included twenty chronic hepatitis $C$ patients with cirrhotic changes, twenty chronic hepatitis $\mathrm{C}$ patients without cirrhotic changes and before taking interferon therapy and Fifteen chronic hepatitis $\mathrm{C}$ patients without cirrhotic changes and after taking antiviral therapy; interferon (PEG-IFN $\alpha 2 a$ 180- $\mu \mathrm{g} /$ week and Ribavirin 800 mg capsule one time daily for 24 weeks). Twenty male healthy individuals were included as the control group (age, and body mass index matched). All patients were taking liver support supplements containing vitamins; C, E, folic acid and carotenoids.

Results: There was a highly significant increase ( $p$ value 0.00001 ) in plasma carbonylated protein level in cirrhotic patients $(44.9 \pm 5.63 \mathrm{nM} / \mathrm{dL})$ as compared to the control group $(22.3 \pm 3.35 \mathrm{mM} / \mathrm{L})$. TAC in serum in cirrhotic patients was significantly decreased to $0.765 \pm 0.249 \mathrm{mM} / \mathrm{L}$ as compared to all other groups. These patients were taking antioxidants vitamins (vitamin $\mathrm{C}$, carotenoids and vitamin $\mathrm{E}$ ), and other supplements known to have antioxidant effects (silimaryn, trace elements), which did not increase their TAC.
\end{abstract}

Conclusions: Carbonylated proteins may play a role in HCV induced liver cirrhosis. The currently used antioxidants did not increase the antioxidant capacity of plasma. New antioxidants as well as inducers of antioxidant enzymes may be helpful in increasing TAC and prevention of formation of carbonylated proteins and liver cirrhosis.

Keywords: Carbonylated proteins; Total antioxidant capacity; HCV hepatitis; Liver cirrhosis; Interferon; Ribavirin

\section{Introduction}

Egypt has a high prevalence of Hepatitis C Virus (HCV), and its complications as liver cirrhosis and hepatocellular carcinoma. Hepatitis $\mathrm{C}$ virus infection represents a major health issue worldwide due to its burden of chronic liver disease and extra hepatic manifestations. HCV hepatitis is treated with antiviral therapy, which includes interferon and ribavirin. The therapy usually extends for 24 weeks or more. Yet, in Egypt, liver cirrhosis is still a complication of HCV hepatitis, even in patients who received the antiviral therapy, which may suggest that additional factors contribute for the cirrhosis. HCV variants with reduced susceptibility to interferon can occur naturally, even before treatment begins [1].

HCV causes oxidative stress by a variety of processes, such as activation of prooxidant enzymes, weakening of antioxidant defenses, organelle damage, and metals unbalance. A focal point, in HCV-related oxidative stress onset, is the mitochondrial failure. Mitochondria have a central role in energy production, metabolism, and metals homeostasis, mainly copper and iron. Furthermore, mitochondria are direct viral targets, because many HCV proteins associate with them. They are the main intracellular free radicals producers and targets [2].

Oxidative stress is a condition of oxidant/antioxidant disequilibrium where there is overproduction of Reactive Oxygen Species (ROS) on one side and a deficiency of enzymatic and non-enzymatic antioxidants on the other side. Examples of non-enzymatic antioxidants are; bilirubin, vitamin $C$, vitamin $E, \beta$ - carotene, and flavonoids. The resulting oxidative stress damages various cellular component including lipids, proteins and nucleic acids inhibiting their normal function. ROS damage to cellular component plays an important role in numerous diseases including cancer, metabolic syndrome, atherosclerosis, cardiovascular diseases, neurological disorders, Alzheimer disease, diabetes mellitus, aging, autoimmune diseases, and chronic inflammatory diseases [3].

Oxidative stress induces reactions in cellular and blood lipids and proteins. ROS can mediate intra- and intermolecular cross-linking of peptides and proteins and fragmentation of polypeptide chains. In addition, protein carbonyls are formed because of the oxidative modifications of proteins. Carbonyl groups are introduced into proteins by two distinct mechanisms: oxidative (direct) and nonoxidative (indirect). Oxidative mechanisms, which are metal catalyzed, involve the direct reaction of certain reactive oxygen species (e.g., hydrogen peroxide and lipid hydro peroxides) with protein side chains. Non-oxidative carbonylation of proteins involves the reaction of the nucleophilic centers in cysteine, histidine or lysine residues with reactive carbonyls (RCOs). RCOs are carbonyl-containing malondialdehyde, acrolein and carbohydrates (e.g., glyoxal, methylglyoxal) [4].

Damage of proteins by oxidative stress could be involved in inflammation-related carcinogenesis. Detection of elevated levels of protein carbonyls in blood or tissues indicates generally a disease associated dysfunction and defective immunological responses and macrophages functions [5].

*Corresponding author: Mahmoud Mohamed Alou-El-Makarem, Department of Medical Biochemistry, Al Azhar University, Cairo, Egypt, Tel: 02-115-400-0554; E-mail: aref48@mail.com

Received March 17, 2014; Accepted July 11, 2014; Published July 16, 2014

Citation: Alou-El-Makarem MM, Moustafa MM, Fahmy MA, Abdel-Hamed AM, Elfayomy KN, et al. (2014) Evaluation of Carbonylated Proteins in Hepatitis C Virus Patients. Mod Chem appl 2: 130. doi:10.4172/2329-6798.1000130

Copyright: (c) 2014 Alou-El-Makarem MM, et al. This is an open-access article distributed under the terms of the Creative Commons Attribution License, which permits unrestricted use, distribution, and reproduction in any medium, provided the original author and source are credited. 
The aim of this work was to determine the plasma level of carbonylated proteins and total antioxidant capacity and evaluate their role in HCV hepatitis patients and HCV induced liver cirrhosis. In addition, the effect of antiviral therapy; interferon and ribavirin on their levels in plasma was evaluated.

\section{Subjects and Methods}

\section{Patients and controls}

This study included 55 male patients with chronic hepatitis $\mathrm{C}$ from the internal medicine department, Damietta, Egypt. The patients were already diagnosed by viral markers.

Twenty male healthy individuals were included as the control group (age, and body mass index matched; Table 1).

Patients were divided into 3 groups:

Group 1: Twenty chronic hepatitis $C$ patients with cirrhotic changes diagnosed by Sonography.

Group 2: Twenty chronic hepatitis C patients without cirrhotic changes and before taking interferon therapy.

Group 3: Fifteen chronic hepatitis $\mathrm{C}$ patients without cirrhotic changes and after taking antiviral therapy; interferon (PEG-IFN a2a $180-\mu \mathrm{g} /$ week and Ribavirin $800 \mathrm{mg}$ capsule one time daily for 24 weeks).

All patients were taking liver support supplements containing vitamins; C, E, folic acid and carotenoids.

\section{Exclusion criteria}

Subjects suffering from any systemic disease or autoimmune disease were excluded from the study. In addition, subjects with positive HBV or have taken HBV vaccine, smokers and obese subjects with BMI $>30$ $\mathrm{kg} / \mathrm{M}^{2}$ were excluded from the study.

Only patients with HCV hepatitis were included in this study.

Written medical consent was signed by all participants, and the protocol of the work was approved by the Ethical Committee of AlAzhar University (Table 1).

All the patients were taking orally liver supporting drugs: Silymarin;

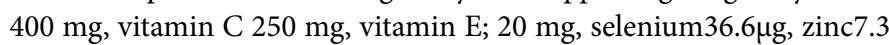
$\mathrm{mg}$ and Glutathione $250 \mathrm{mg}$, daily.

\begin{tabular}{|c|c|c|c|c|}
\hline & & Weight $\mathbf{( k g )}$ & Height $\mathbf{( c m )}$ & BMI (kg/M $\left.\mathbf{M}^{\mathbf{2}}\right)$ \\
\hline Control & Mean \pm SD & $88.7 \pm 7.5$ & $177.85 \pm 6.7$ & $28.02 \pm 1.8$ \\
\hline Group 1 & Mean \pm SD & $84.2 \pm 10.7$ & $176.85 \pm 7.9$ & $26.81 \pm 2.1$ \\
\hline Group 2 & Mean \pm SD & $83.8 \pm 9.7$ & $178.5 \pm 9.8$ & $26.29 \pm 2.5$ \\
\hline Group 3 & Mean \pm SD & $85.4 \pm 7.3$ & $182 \pm 9.7$ & $25.8 \pm 2.4$ \\
\hline
\end{tabular}

Table 1: Weight, height and BMI of patients and control group.

\begin{tabular}{|c|c|c|c|c|}
\hline & Control & Group 1 & Group 2 & Group 3 \\
\hline Mean \pm SD & $3.9 \pm 0.38$ & $2.04 \pm 0.567$ & $4.04 \pm 0.377$ & $3.8 \pm 0.376$ \\
\hline \multirow{2}{*}{ Control } & t-test & 12.417 & -0.835 & 1.133 \\
& P-value & $0.0003^{\star}$ & 0.409 & 0.265 \\
\hline \multirow{2}{*}{ HCV before interferon } & t-test & -13.1 & -------- & ---------- \\
& P-value & $0.0002^{\star}$ & & \\
\hline \multirow{2}{*}{ HCV after interferon } & t-test & - & 1.914 & --------- \\
\hline
\end{tabular}

*Highly significant

Table 2: Serum albumin in different groups $(\mathrm{g} / \mathrm{dL})$.

\section{Blood samples}

Blood samples were obtained from patients and healthy controls after 12 hours of fasting.

Two $\mathrm{mL}$ in polypropylene tubes, left to clot for 20 minutes at $37^{\circ} \mathrm{C}$, centrifuged at $3000 \mathrm{~g}$ for 10 minutes and serum was separated and used for determination of ALT, AST, alkaline phosphatase, and albumin.

Four $\mathrm{mL}$ in polypropylene tubes containing sodium citrate as an anticoagulant for determination of carbonylated protein level and TAC in plasma. Blood was centrifuged for 10 minutes at $3000 \mathrm{~g}$ immediately after collection and plasma was removed and stored at $<-80^{\circ} \mathrm{C}$ till assay.

\section{Methods}

Serum albumin, Alanine Transaminase (ALT), Aspartate Transaminase (AST) and Alkaline Phosphatase (ALP) were assayed on Roche/Hitachi 902 chemistry auto analyzer, by using kits supplied by Roche Diagnostic, Germany [6].

Total plasma antioxidative capacity was determined by the reaction of antioxidants in the sample with a defined amount of exogenously provided hydrogen peroxide $\left(\mathrm{H}_{2} \mathrm{O}_{2}\right)$. The antioxidants in the sample eliminate a certain amount of $\mathrm{H}_{2} \mathrm{O}_{2}$, The residual $\mathrm{H}_{2} \mathrm{O}_{2}$ was determined calorimetrically by an enzymatic reaction which involves the conversion of 3,5, dichloro-2-hydroxy benzene sulphonate to a colored product which was measured at $505 \mathrm{~nm}$ [7].

Carbonylated proteins in plasma were measured using Cayman's Protein Carbonyl Colorimetric Assay Kit. The kit utilized the DNPH reaction as described by Levine et al. [8]. After incubation of DNPH with samples, trichloroacetic acid $10 \%(\mathrm{w} / \mathrm{v})$ was added and samples were centrifuged at $11,000 \mathrm{~g}$ in a cooling centrifuge. The precipitates were washed with a mixture of ethanol/ethyl acetate, $1: 1(\mathrm{v} / \mathrm{v})$ three times and then dissolved in guanidine hydrochloride $6 \mathrm{M}(\mathrm{pH} 2.3)$. The absorbance was then measured at $360 \mathrm{~nm}$ and the concentration of $\mathrm{CO}$ groups was calculated using the molar extinction coefficient (e) of $22,000 \mathrm{~cm}^{-1} \mathrm{M}^{-1}$.

Protein concentration of the samples was determined by the Bradford's assay [9] using a microplate reader (Bio-Rad 3550; Bio-Rad, Hercules, CA) at $595 \mathrm{~nm}$ and BSA as standard.

\section{Statistical analysis}

Results were expressed as Mean \pm Standard Deviation (SD). Comparison between groups was done using Student's $t$ test with significance defined as $\mathrm{p} \leq 0.05$.

\section{Results}

\section{Serum albumin}

Serum albumin level was $3.9 \pm 0.38 \mathrm{~g} / \mathrm{dl}$ in the control group. Serum albumin levels were $2.04 \pm 0.567,4.04 \pm 0.377$ and $3.8 \pm 0.376 \mathrm{~g} / \mathrm{dl}$ ingroup 1, 2 and 3 respectively (Table 2 ). There was a highly significant decrease in albumin level in cirrhotic patients (group 1) compared to all other groups.

\section{Plasma total antioxidant capacity}

Total plasma antioxidant capacity levels were $1.55 \pm 0.272,2.04 \pm$ 0.290 and $2.63 \pm 0.193 \mathrm{mmol} /$ liter in the control group, group 2 and group 3 respectively. Plasma TAC in chronic HCV hepatitis patients before and after antiviral therapies were therefore, significantly increased. Plasma TAC in group 1 (cirrhotic patients) was significantly decreased to $0.765 \pm 0.249 \mathrm{mmol} /$ liter as compared to all other groups (Table 3). 


\begin{tabular}{|c|c|c|c|c|}
\hline & Control & Group 1 & Group 2 & Group 3 \\
\hline Mean \pm SD & $1.55 \pm 0.272$ & $0.765 \pm 0.249$ & $2.04 \pm 0.290$ & $2.63 \pm 0.193$ \\
\hline Control & t-test & 9.545 & -5.453 & -13.067 \\
\hline $\begin{array}{c}\text { HCV before } \\
\text { interferon }\end{array}$ & t-test & $0.0004^{*}$ & $0.002^{*}$ & $0.0003^{*}$ \\
\hline $\begin{array}{c}\text { HCV after } \\
\text { interferon }\end{array}$ & $\begin{array}{c}\text { t-test } \\
\text { P-value }\end{array}$ & -14.88 & ------- & --------- \\
\hline
\end{tabular}

*Highly significant

Table 3: Total anti-oxidant capacity in plasma ( $\mathrm{mmol} / \mathrm{litre})$.

\begin{tabular}{|c|c|c|c|c|}
\hline & Control & Group 1 & Group 2 & Group 3 \\
\hline Mean \pm SD & $22.3 \pm 3.35$ & $44.9 \pm 5.63$ & $27.22 \pm 2.92$ & $24.9 \pm 2.83$ \\
\hline Control & $\begin{array}{c}\text { t-test } \\
\text { P-value }\end{array}$ & $\begin{array}{l}-15.414 \\
0.00001^{*}\end{array}$ & $\begin{array}{l}-4.916 \\
0.003^{*}\end{array}$ & $\begin{array}{l}-2.43 \\
0.21\end{array}$ \\
\hline $\begin{array}{l}\mathrm{HCV} \text { before } \\
\text { interferon }\end{array}$ & $\begin{array}{c}\text { t-test } \\
\text { P-value }\end{array}$ & $\begin{array}{l}12.475 \\
0.0003^{*}\end{array}$ & 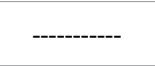 & ------ \\
\hline $\begin{array}{l}\mathrm{HCV} \text { after } \\
\text { interferon }\end{array}$ & $\begin{array}{c}\text { t-test } \\
\text { P-value }\end{array}$ & & $\begin{array}{l}2.312 \\
0.027\end{array}$ & \\
\hline
\end{tabular}

"Highly significant

Table 4: Plasma carbonylated proteins in different groups (nM/dL).

\begin{tabular}{|l|l|c|c|c|c|}
\hline & & $\begin{array}{c}\text { AST } \\
\text { U/dl }\end{array}$ & $\begin{array}{c}\text { ALT } \\
\text { U/dl }\end{array}$ & $\begin{array}{c}\text { AST/ALT } \\
\text { (AAR) }\end{array}$ & $\begin{array}{c}\text { ALP } \\
\text { U/L }\end{array}$ \\
\hline Control & Mean \pm SD & $25.8 \pm 4.3$ & $25.1 \pm 3.7$ & $1.03 \pm 0.1$ & $79.7 \pm 22.3$ \\
\hline Group 1 & Mean \pm SD & $24.8 \pm 3.7$ & $25.05 \pm 3.1$ & $0.99 \pm 0.06$ & $89.45 \pm 27.8$ \\
\hline Group 2 & Mean \pm SD & $124.5 \pm 27.4^{*}$ & $131.35 \pm 20.8^{*}$ & $0.97 \pm 0.04$ & $218.45 \pm 50.3^{*}$ \\
\hline Group 3 & Mean \pm SD & $25.8 \pm 3.7$ & $27.87 \pm 3.8$ & $0.93 \pm 0.08$ & $88 \pm 22.2$ \\
\hline
\end{tabular}

'Statistical significant when compared to the control group ( $p$-value $\leq 0.01$ )

Table 5: Serum aminotransferases, alkaline phosphatase (ALP) and AST/ALT ratio (AAR) in control group and patients.

\section{Plasma carbonylated proteins}

Carbonylated proteins level in plasma of HCV patients with cirrhosis was $44.9 \pm 5.63 \mathrm{nM} / \mathrm{dL}$. Carbonylated proteins levels in control group, and group 3 were $22.3 \pm 3.35$, and $24.9 \pm 2.83 \mathrm{mM} / \mathrm{L}$ respectively. There was a highly significant increase in carbonylated protein level in cirrhotic patients compared to all other groups. Carbonylated proteins levels in-group 2 was $27.22 \pm 2.92 \mathrm{nM} / \mathrm{dL}$, showing a significant increase as compared to control group and group 3 (Table 4).

Serum aminotransferases, alkaline phosphatase and AST/ ALT ratio (AAR) in control group and patients

Serum levels of AST, ALT and ALP in HCV hepatitis patients were significantly high (AST; $124.5 \mathrm{IU} / \mathrm{dl}$, ALT; $131.35 \mathrm{IU} / \mathrm{dl}$, ALP; 218.45 $\pm 50.3 \mathrm{U} / \mathrm{L}$ ) when compared to the control group (AST; $25.8 \pm 4.3$ $\mathrm{IU} / \mathrm{dl}, \mathrm{ALT} ; 25.1 \pm 3.7 \mathrm{IU} / \mathrm{dl}, 79.7 \pm 22.3 \mathrm{U} / \mathrm{L})$. The levels of serum aminotransferases and ALP in patients taking interferon and ribavirin therapy, decreased to near control values. Interferon therapy in these patients decreased the inflammatory process in hepatocytes. AAR ratio in cirrhotic patients in this study was $0.99(24.8 / 25.05)$. The ratio was $1.03 \pm 0.1,0.97 \pm 0.04$ and $0.93 \pm 0.08$ in control group, group 2 and group 3 respectively. There was no statistical significance between the values of all groups (Table 5).

\section{Discussion}

\section{Serum albumin}

HCV hepatitis is an acute to chronic inflammation of hepatocytes, which may develop into liver cirrhosis. The levels of serum albumin were significantly decreased in patients with HCV hepatic cirrhosis $(2.04 \mathrm{~g} / \mathrm{dl})$ compared to the control group $(3.94 \mathrm{~g} / \mathrm{dl})$. The changes in the level of albumin were not significant in HCV hepatitis patients without cirrhosis. The low level of serum albumin and cirrhotic changes in liver parenchyma may lead to ascites and edema in lower limbs. In humans, albumin synthesis takes place only in the liver. Albumin is not stored by the liver but is secreted into the portal circulation as soon as it is manufactured. Under physiological conditions, albumin may have significant antioxidant potential. This may be related to the abundance of sulfhydryl (-SH) groups on the albumin molecule [10].

Albumin therapy is recommended in refractory ascites not responsive to diuretics. Indications for albumin therapy are linked to the antioxidant activity of albumin. Albumin exchange has emerged as promising liver support therapies for liver failure and other toxic syndromes. They are designed to remove a broad range of blood-borne toxins and to restore normal functions of the circulating albumin by replacing defective forms of albumin and albumin molecules saturated with toxins with normal albumin [11].

\section{Serum aminotransferases and alkaline phosphatase}

The most commonly used markers of hepatocyte injury are AST (cytosolic and mitochondrial forms), and ALT (cytosolic). As markers of hepatocellular injury, AST and ALT also lack some specificity because they are found in other tissue. HCV is one of the risk factors for hepatocellular carcinoma. AST/ALT ratio (AAR) may be used as a possible surrogate marker for identifying patients at high risk for developing hepatocellular carcinoma. AAR $>1.4$ might be a useful tool to identify candidates at high risk for HCC. This ratio in cirrhotic patients in this study was $0.99(24.8 / 25.05)$. The ratio was $1.03 \pm 0.1$, $0.99 \pm 0.06,0.97 \pm 0.04$ and $0.93 \pm 0.08$ in control group, group 1, group 2 and group 3 respectively. There was no statistical significance between the values of all groups. AAR in all patients was lower than the cut value of suspecting malignancy [12].

Alkaline phosphatase in serum of HCV hepatitis patients without antiviral therapy, and using only hepatic supportive drugs was significantly increased. inflammation of the bile ducts occurs frequently in chronic hepatitis $\mathrm{C}$, and decreases in response to IFN therapy [13].

\section{Carbonylated proteins}

Protein carbonyl group can be generated directly by amino acid oxidation or indirectly by forming adduct with lipid peroxidation product. Carbonylation is an irreversible post-translation modification that often leads to loss of protein function. Carbonylated proteins are a stable marker of severe oxidative stress because damage to the protein structure is irreversible and may cause an inhibition of their enzymatic activity or an increased susceptibility to proteolysis [14].

Detection of elevated levels of protein carbonyls in blood or tissues, indicates generally a disease associated dysfunction and defective immunological responses and macrophages functions [15].

The carbonylated modification of protein may lead to proteins that are recognized as non-self by the immune system. The resultant antibody will cross react with normal tissue proteins so initiating autoimmune diseases [16]. Chemicals, which increase ROS production and oxidative stress damage to protein, may lead to dys-morphogenesis and teratogenesis in fetus [17].

ROS interfere with the expression of number of genes, signal transduction pathway, and are thus instrumental in the process of carcinogenesis. The abnormal behaviors of neoplastic cells can be traced to an alteration in cell signaling mechanisms such as cytoplasmic receptor for tyrosine kinas, altered level of growth factor, proteins of transcription apparatus, protein involved in cell cycle. All these protein can be oxidized and carbonylated by ROS. Permanent modification 
of genetic materials and protein responsible for DNA replication and repair and control of cell cycle by oxidative damage represents the first step in carcinogenesis. The significantly high levels of carbonylated proteins in $\mathrm{HCV}$ cirrhotic patients may suggest that they are at risk of hepatocellular carcinoma. These protein oxidations should be treated before they are initiated at the stage of HCV hepatitis [18].

\section{Total anti-oxidant capacity}

Assay of Total anti-oxidant capacity measures a complex of nonenzymatic antioxidants present in blood, which include exogenous antioxidants such as ascorbic acid, $\alpha$ tocopherol, $\beta$ carotene and polyphenols. It also measures the endogenous antioxidants such as reduced glutathione, uric acid, and bilirubin. All patients were taking antioxidants including Silymarin and ascorbic acid, as routine since they were diagnosed as hepatitis patients even before the cause of hepatitis was determined for about three months before enrolled in this study. Silymarin flavonolignans used by patients in this study as polyphenol antioxidant are rapidly absorbed [19]. Silymarin displays anti-inflammatory effects on $\mathrm{T}$ lymphocytes in vitro and modest nonspecific immunomodulatory effects in vivo [20]. Ascorbic acid inhibits intracellular ROS generation and reduces the ethanol-induced inflammation in hepatocytes [21].

Taking antioxidants may explain the high level of blood total antioxidants in HCV hepatitis patients as compared to the control group. Supplementation of exogenous antioxidants did not increase antioxidant status in cirrhotic patients. The low levels of TAC in patients with liver cirrhosis may be either due to decrease in the level of plasma albumin or in the synthesis of glutathione and other endogenous antioxidants. In addition, it may be due to increased ROS production in the body.

New antioxidants as well as inducers of antioxidant enzymes; $\mathrm{Mn}$ / superoxide dismutase and catalase, may be helpful in increasing TAC and prevention of formation of carbonylated proteins. Drugs, which can increase specifically proteolysis of carbonylated proteins, may be tried in liver cirrhosis patients [22].

\section{Conclusion}

Carbonylated proteins are irreversible posttranslational modification, which may interfere with the normal homeostasis of cell growth inducing liver cirrhosis and risk of malignancy [23-25]. There was a highly significant increase ( $p$ value 0.00001 ) in carbonylated protein level in cirrhotic patients $(44.9 \pm 5.63 \mathrm{n} \mathrm{M} / \mathrm{dL})$ as compared to the control group $(22.3 \pm 3.35 \mathrm{mM} / \mathrm{L})$ [26-28].

TAC in plasma in cirrhotic patients was significantly decreased to $0.765 \pm 0.249 \mathrm{mM} / \mathrm{L}$ as compared to all other groups [29]. These patients were taking antioxidants vitamins (vitamin $\mathrm{C}$, carotenoids and vitamin E), and other supplements known to have antioxidant effects (silimaryn, trace elements), which did not increase their TAC [30,31].

\section{References}

1. Pawlotsky JM (2011) Treatment failure and resistance with direct-acting antiviral drugs against hepatitis C virus. Hepatology 53: 1742-1751.

2. Arciello M, Gori M, Balsano C (2013) Mitochondrial dysfunctions and altered metals homeostasis: new weapons to counteract HCV-related oxidative stress. Oxid Med Cell Longev 2013: 971024.

3. Liochev SI (2013) Reactive oxygen species and the free radical theory of aging Free Radic Biol Med 60: 1-4.

4. Dkhar P, Sharma R (2011) Amelioration of age-dependent increase in protein carbonyls of cerebral hemispheres of mice by melatonin and ascorbic acid. Neurochem Int 59: 996-1002.
5. Thanan R, Oikawa S, Yongvanit P, Hiraku Y, Ma N, et al. (2012) Inflammation-induced protein carbonylation contributes to poor prognosis for cholangiocarcinoma. Free Radic Biol Med 52: 1465-1472.

6. Withold W, Rick W (1994) Evaluation of an immunoradiometric assay for bone alkaline phosphatase mass concentration in human sera. Eur J Clin Chem Clin Biochem 32: 91-95.

7. Koracevic D, Koracevic G, Djordjevic V, Andrejevic S, Cosic V (2001) Method for the measurement of antioxidant activity in human fluids. J Clin Pathol 54 356-361.

8. Levine RL, Garland D, Oliver CN, Amici A, Climent I, et al. (1990) Determination of carbonyl content in oxidatively modified proteins. Methods Enzymol 186: 464-478.

9. Bradford MM (1976) A rapid and sensitive method for the quantitation of microgram quantities of protein utilizing the principle of protein-dye binding. Anal Biochem 72: 248-254

10. Nicholson JP, Wolmarans MR, Park GR (2000) The role of albumin in critical illness. Br J Anaesth 85: 599-610

11. Rozga J, Piątek T, Małkowski P (2013) Human albumin: old, new, and emerging applications. Ann Transplant 18: 205-217.

12. Tseng PL, Wang JH, Hung CH, Tung HD, Chen TM, et al. (2013) Comparisons of noninvasive indices based on daily practice parameters for predicting liver cirrhosis in chronic hepatitis B and hepatitis C patients in hospital and community populations. Kaohsiung J Med Sci 29: 385-395.

13. Banner BF, Allan C, Smith L, Savas L, Bonkovsky HL (1996) Effect of interferon therapy on bile duct inflammation in hepatitis C. Virchows Arch 428: 253-259.

14. Hopps E, Caimi G (2013) Protein oxidation in metabolic syndrome. Clin Invest Med 36: E1-8.

15. Bozinovski S, Vlahos R, Zhang Y, Lah LC, Seow HJ, et al. (2011) Carbonylation caused by cigarette smoke extract is associated with defective macrophage immunity. Am J Respir Cell Mol Biol 45: 229-236.

16. Madian AG, Regnier FE (2010) Proteomic identification of carbonylated proteins and their oxidation sites. J Proteome Res 9: 3766-3780.

17. Madian AG, Myracle AD, Diaz-Maldonado N, Rochelle NS, Janle EM, et al (2011) Determining the effects of antioxidants on oxidative stress induced carbonylation of proteins. Anal Chem 83: 9328-9336.

18. Han Y, Chen JZ (2013) Oxidative stress induces mitochondrial DNA damage and cytotoxicity through independent mechanisms in human cancer cells. Biomed Res Int 2013: 825065.

19. Zhu HJ, Brinda BJ, Chavin KD, Bernstein HJ, Patrick KS, et al. (2013) An assessment of pharmacokinetics and antioxidant activity of free silymarin flavonolignans in healthy volunteers: a dose escalation study. Drug Metab Dispos 41: 1679-1685.

20. Adeyemo O, Doi H, Rajender Reddy K, Kaplan DE (2013) Impact of oral silymarin on virus- and non-virus-specific T-cell responses in chronic hepatitis C infection. J Viral Hepat 20: 453-462.

21. Abhilash PA, Harikrishnan R, Indira M (2013) Ascorbic acid is superio to silymarin in the recovery of ethanol-induced inflammatory reactions in hepatocytes of guinea pigs. J Physiol Biochem 69: 785-798.

22. Robbins $D$, Zhao Y (2011) The role of manganese superoxide dismutase in skin cancer. Enzyme Res 2011: 409295.

23. Bergmeyer HU, Horder M, Rej R (1986) International Federation of Clinical Chemistry (IFCC) Scientific Committee, Analytical Section: approved recommendation (1985) on IFCC methods for the measurement of catalytic concentration of enzymes. Part 3. IFCC method for alanine aminotransferase (L-alanine: 2-oxoglutarate aminotransferase, EC 2.6.1.2). J Clin Chem Clin Biochem 24: 481-495.

24. Choi J (2012) Oxidative stress, endogenous antioxidants, alcohol, and hepatitis C: pathogenic interactions and therapeutic considerations. Free Radic Biol Med 52: $1135-1150$.

25. Johnston DE (1999) Special considerations in interpreting liver function tests Am Fam Physician 59: 2223-2230.

26. Doumas BT, Watson WA, Biggs HG (1971) Albumin standards and the measurement of serum albumin with bromcresol green. Clin Chim Acta 31: 8796. 
Citation: Alou-El-Makarem MM, Moustafa MM, Fahmy MA, Abdel-Hamed AM, El-fayomy KN, et al. (2014) Evaluation of Carbonylated Proteins in Hepatitis C Virus Patients. Mod Chem appl 2: 130. doi:10.4172/2329-6798.1000130

27. Hull MC, Morris CG, Pepine CJ, Mendenhall NP (2003) Valvular dysfunction and carotid, subclavian, and coronary artery disease in survivors of hodgkin lymphoma treated with radiation therapy. JAMA 290: 2831-2837.

28. Mirici-Cappa F, Caraceni P, Domenicali M, Gelonesi E, Benazzi B, et al. (2011) How albumin administration for cirrhosis impacts on hospital albumin consumption and expenditure. World J Gastroenterol 17: 3479-3486.

29. Seronello S, Montanez J, Presleigh K, Barlow M, Park SB, et al. (2011) Ethanol and reactive species increase basal sequence heterogeneity of hepatitis $C$ virus and produce variants with reduced susceptibility to antivirals. PLoS One 6: e27436.
30. Suski JM, Lebiedzinska M, Bonora M, Pinton P, Duszynski J, et al. (2012) Relation between mitochondrial membrane potential and ROS formation. Methods Mol Biol 810: 183-205

31. Wahlefeld AW, Herz G, and Bernt E (1972) Modification of Malloy-Evelyn method for a simple, reliable determination of total bilirubin in serum. Scand $J$ Clin Lab Invest 29:11-12. 